\title{
Assessing and Planning Sustainable City Region Food Systems: Insights from Two Latin American Cities
}

\author{
Marielle Dubbeling ${ }^{1, *}$, Guido Santini ${ }^{2}$, Henk Renting ${ }^{1}$, Makiko Taguchi ${ }^{2}$, Louison Lançon ${ }^{2}$, \\ Juan Zuluaga ${ }^{3}$, Luca de Paoli ${ }^{3}$, Alexandra Rodriguez ${ }^{4}$ and Verónica Andino 5 \\ 1 RUAF Foundation; Leusden 3830 AK, The Netherlands; h.renting@ruaf.org \\ 2 Food and Agriculture Organization of the United Nations (FAO), Food for the Cities programme, \\ Rome 00153, Italy; Guido.Santini@fao.org (G.S.); Makiko.Taguchi@fao.org (M.T.); \\ Louison.Lancon@fao.org (L.L.) \\ 3 Food and Agriculture Organization of the United Nations (FAO), Office Medellín, Medellín, Colombia; \\ juan.zuluaga@fao.org.co (J.Z.); lucadepaoli@hotmail.com (L.d.P.) \\ 4 Metropolitan Agency for Economic Development CONQUITO, Quito, Ecuador; arodriguez@conquito.org.ec \\ 5 Consultant for RUAF Foundation, Quito, Ecuador; veroandino@gmail.com \\ * Correspondence: m.dubbeling@ruaf.org
}

Received: 31 May 2017; Accepted: 24 July 2017; Published: 17 August 2017

\begin{abstract}
In the context of growing urbanisation, urban poverty, and climate change impacts, the importance of urban food security and urban food systems is increasingly recognised by both local and national governments, as well as international actors. There is also a growing understanding that urban development and food systems cannot be decoupled from rural development given the multiple impacts that urban areas have on their surroundings. In recent years the concept of City Region Food Systems (CRFS) has emerged as a promising approach to support local governments, policy makers, and multi-stakeholder bodies in making informed decisions to improve urban and regional food system sustainability and resilience, while taking into account a more integrated approach to territorial development across urban and rural areas. This paper is based on an ongoing FAO and RUAF programme of assessing and planning City Region Food Systems, currently implemented in eight city regions in Canada, Colombia, Ecuador, Senegal, Sri Lanka, The Netherlands, and Zambia. The paper analyses the content, definition and delimitations of the concept of City Region Food Systems by presenting two case studies from Latin America (Quito and Medellín), and discusses first advances in policy uptake and territorial food planning.
\end{abstract}

Keywords: city region food systems; food planning; governance; urban food provisioning; urban-rural linkages; resilience; food system assessment

\section{Introduction}

At present, more than 50 percent of the world's population is living in urban areas and this is expected to rise to 66 percent by 2050, a growth that will especially occur in the developing world [1]. The transformation of food supply systems that occurred in the last 60 years contributed to a multidimensional rural-urban divide: a social and cognitive division with the loss of control over food by urban dwellers, a geographic division with the lengthening of value chains, a political divide with fragmented government interventions, and a concentration of food system control and power in a reduced number of players at the cost of agricultural producers and consumers $[2,3]$. These transformation processes are increasingly intertwined with wider problems, such as food and nutrition insecurity in cities, urban and rural poverty, climate change impacts, and unsustainable natural resource management $[4,5]$. Public concern over: these multiple problems and a growing 
support of consumers and wider society for healthy and safe food; improved food governance and transparency; and, more generally, for food production and consumption patterns that contribute to sustainable development, in recent years has contributed to a growing interest in City Region Food Systems (CRFS) $[2,6,7]$.

Food system governance and planning has for a long time been absent in urban planning and city policy making [8]. Nevertheless, city, metropolitan, and national governments have started prominently and actively to take part in local and (inter)national dialogue on the future of urban food and nutrition security. This is evidenced by the Milan Urban Food Policy Pact, currently signed by over 140 cities around the world [9], as well as by agricultural ministers of 65 countries who signed a declaration in early 2016 recognising the need for giving more attention to urban food security [10]. These and other recent international declarations by (international) support organisations and cities call for an increased focus on the role that cities and city regions (could) play in enhancing food security, local economic development, and resilient and sustainable development of both urban and rural areas through the development of CRFS. In the New Urban Agenda, adopted in Quito last October 2016, which will guide implementation of the Sustainable Development Goals for the coming years, food security and nutrition are mentioned as key elements of urban and territorial sustainability [11]. It is also recognised that food systems are closely related to other local and regional government sectors, including organic waste management, public health, transport, markets, enterprise creation in the food system, consumption and food insecurity/malnutrition, land use planning, and climate change adaptation strategies, amongst others.

At the same time, these and other actors are beginning to recognise that the city region represents a relevant governance and territorial scale to contribute to solving broader issues affecting both urban and rural areas. Indeed, challenges like land use, food production, environmental management, transport, and market and producer-consumer linkages can often best be addressed by linking rural and urban communities in a given city region $[2,6,12]$.

A city region perspective, associated with a food system outlook, thus represents a relevant and efficient approach to address broad challenges impacting both urban and rural areas and dwellers, and build more resilient, fair, and sustainable food systems and territories. As recent case studies on city regions around the world illustrate:

1. Food produced in peri-urban areas and rural hinterlands contributes to supplies for both urban areas and their rural surroundings, while urban areas supply the markets upon which agricultural livelihoods depend;

2. Rural watersheds supply drinking water to urban areas and provide irrigation for urban, peri-urban, and rural agriculture. Sustainable forms of urban water management can provide financial incentives for the preservation of such (agricultural) watersheds;

3. Food losses and waste can be prevented, reduced, and managed, including through the recovery and redistribution of safe and nutritious food for human consumption along the food supply chain from production to consumption, spanning both rural and urban territories;

4. Organic and agricultural waste resources produced in urban and rural areas can be used to generate energy and fertilisers, which are used in urban and rural areas, respectively; and

5. Preservation and sustainable management of agricultural lands in rural and peri-urban areas can help to enhance water retention, reduce flooding, or mitigate increasing temperatures, thus reducing the climate change vulnerability of both urban and rural areas [12,13].

These same studies stress the need to integrate food into the urban agenda, enabling the involvement of all key local stakeholders, with particular attention to smallholder farmers and urban dwellers, and ensuring coordination and collaboration across horizontal (different government departments and sectors) as well as vertical governance (across local, provincial, and national authorities) levels. 
However, there is a need to further operationalise the concept of CRFS to be actually included in policy and planning agendas in given city regions. This has the objectives of:

- CRFS characterisation: to understand boundaries, elements, and relations in CRFS and define possible indicators;

- Policy operationalisation: focused data to define policy actions and strategies;

- Policy monitoring: focused data to measure policy impacts and changes over time in relation to baseline data;

- Policy communication: transparent and understandable data to communicate policy aims and impacts to wider audiences and influence policy uptake.

Since early 2015, FAO and RUAF have been developing an approach to implement CRFS assessments in a number of pilot cities across the globe. This paper describes the assessment methodology, and explores how the CRFS concept can facilitate the integration of food-related issues into urban planning with a focus on two case studies of Latin American cities.

\section{The City Region Food System Concept: Developing Territorial Approaches to Urban Food Systems}

The CRFS concept came up in response to a number of complementary developments in policy and scientific debates. The concept emerged over 2012-2013 in discussions amongst UN Agencies, associations of local authorities, NGOs, and the research community, and was defined in a 2013 multi-stakeholder consultation as "the complex network of actors, processes and relationships to do with food production, processing, marketing, and consumption that exist in a given geographical region that includes a more or less concentrated urban centre and its surrounding peri-urban and rural hinterland; a regional landscape across which flows of people, goods and ecosystem services are managed" [6]. Although contexts differ across cities and regions, in all situations, such urban-rural partnerships and inter-municipal cooperation extend beyond traditional administrative boundaries. It is for this reason that the concept of a city region has been coined, to be able to review the relationship between cities and their surrounding areas in a more sustainable way and to be able to promote stronger inter-linkages from urban to rural areas as, amongst others, hubs for food production and as providers of natural resources and ecosystem services [13].

The food provisioning system of any city across the globe, whether small or large, is always a hybrid food system, i.e., combining different modes of food provisioning and consumption (institutional, retail, street foods, etc.). Some cities are mainly, though not exclusively, fed by urban, peri-urban, and nearby rural farms and food processors, while other cities rely largely, though not entirely, on food produced and processed in other countries or continents [14,15]. In all cases, however, food systems link rural and urban communities in a region within a country, across regions, and sometimes between continents. Cities and urban food supply systems play an important role in shaping their surrounding and more distant rural areas where land use, food production, environmental management, transport and distribution, marketing, consumption, and waste generation is concerned.

In theoretical terms, the CRFS concept builds on and brings together a number of different traditions and epistemologies. First of all, it is to be considered as an attempt to develop a territorial approach to urban food systems and its associated rural-urban linkages. While territorial approaches have been strongly developed and widely accepted in rural development studies [16-18], this has hardly been the case for urban-oriented food studies. At the same time, territorial linkages, not only in terms of food-market relations between urban and rural areas, but also nutrient, water, and energy metabolism within cities and the territorial embeddedness of food systems, are increasingly gaining attention.

Secondly, the CRFS concept builds on debates around the earlier concept of 'foodshed' [19]. Starting from ecosystem considerations, the foodshed approach proposes that the land and what it can grow defines the perimeters of a food region. It puts food at the centre of identifying what is possible and moves us away from the market considerations as the dominant parameter for 
defining food sourcing and supply chains. Following pioneering work by Hedden and Getz [20,21], Kloppenberg describes a foodshed as "streams of foodstuffs running into a particular locality, their flow mediated by the features of both natural and social geography" ([22], p. 12). These material flows between different places are negotiated by both the physical world as well as by people and their cultures. A foodshed thereby reflects the capacity for production and distribution of food for the residing population of a given geographic location [23]. The foodshed concept thus reconstructs the geography of food systems by compelling social and political decisions on food to be orientated within specific delineated spaces [24].

Thirdly, the CRFS concept builds on the extensive scientific literature on urban food governance that developed over the last decade $[25,26]$. The literature stresses the need to develop new governance modes and structures to address policy challenges in the transition towards sustainability, resilience, and social justice $[27,28]$. This concerns, on the one hand, the need to enhance vertical governance relations, i.e., between policy interventions at different territorial scales going from the city and its neighbourhoods to the regional, national, and international policy levels. On the other hand, attention is needed for improvement of horizontal governance relations-not only between different sectoral and thematic policy areas at each scale, but also for the involvement of relevant stakeholder categories in multi-actor governance processes representing all parts of the 'governance triangle' including state, civil society, and private sector [18,29-31].

Fourth, and finally, the CRFS concept builds on the empirical reality of urban and regional food policy initiatives that are emerging around the world and that are increasingly also being theorised in food studies and policy and innovation studies [9,12,28,32]. These initiatives can be considered as social and policy innovation labs in which new policy approaches and measures are being tested and co-developed, and also increasingly forming the basis for exchange of best policy practices within communities of practice of policy makers and food practitioners, as is the case with follow-up initiatives of the Milan Urban Food Policy Pact [9]. Emerging food policy initiatives also provide concrete expression of concepts such as food democracy and food sovereignty which, until recently, had been largely applied to rural contexts $[27,33,34]$.

From this perspective, a CRFS approach provides a critical lens for analysis, and at the same time supports transformation in governance structures and policy development on the ground. Working at the city region level can be a means to unpack the complexity of urban food and associated rural urban linkages to a practical level, with food being the entry point or common denominator that brings down broader issues such as human rights, climate change, and resilience to a digestible form, and providing cities and metropolitan regions with practical strategies to address broader issues [35].

The term 'City region' refers not only to megacities and the immediate, proximate peri-urban and rural areas surrounding them, but also to small and medium-sized towns that can serve as 'stepping stones' to link more remote small-scale producers and their agricultural value chains to urban centres and markets [36].

\section{From Theory to Practice: Operationalising the CRFS Concept}

\subsection{The FAO and RUAF Approach to Assessing and Strengthening CRFS}

FAO and RUAF are jointly implementing a programme to assess CRFS in different city regions in the world. The programme builds on the demand to better understand and operationalise the concept of CRFS as a basis for informed decision making and further planning, and to prioritise investments and design food policies and strategies which aim at improving the resilience and sustainability of the entire food system. In doing so, the approach addresses the challenges of food security and nutrition, natural resource management, economic development and social inclusion, and the strengthening of rural urban linkages. The programme is being implemented in eight city regions globally: Colombo (Sri Lanka), Dakar (Senegal), Kitwe and Lusaka (Zambia), Medellín (Colombia), Quito (Ecuador), Toronto (Canada), and Utrecht (The Netherlands). 
The starting point of the approach is to assess, characterise, and map the food system in a city region. The assessment methodology adopts a definition of food systems that encompassess "all the elements (environment, people, inputs, processes, infrastructures, institutions, etc.) and activities that relate to the production, processing, distribution, preparation and consumption of food, and the outputs of these activities, including socio-economic and environmental outcomes" [37]. Additionally, it analyses different sustainability dimensions of the food system in its specific territorial context.

The city region boundaries that define the CRFS are locality-specific and are established by taking into account different local criteria and perceptions of local policy actors and stakeholders of these. Relevant categories of criteria include: natural conditions (agro-ecological zones, watersheds, valleys, etc.), jurisdictional boundaries, social coherence and regional identities, and flows of produce and resources between the city and its surroundings. On the other hand, often practical considerations related to data availability are an important consideration that condition the possibilities, and the limitations of implementing a CRFS assessment in a given territorial area.

The city region food system approach provides suggestions for conscious and knowledge-based policies to foster a resilient balance of the food supply from global and local sources. Therefore, for different aspects of the food system, different geographical delimitations may be appropriate. While regional food production can be considered at a specific territorial level (the city region), boundaries for regional food provisioning require other territorial dimensions (with surrounding areas, the wider province) to be taken into account. This is to say that definitions of city region are locally context-specific, and diverse.

A comprehensive set of key questions was developed to describe the city region food system in its different elements and dimensions. These include questions to understand: where the food consumed in a given city region comes from and what is the state of natural resources that support the production; which companies prepare/manufacture the food consumed in the city region; who supplies the food to businesses/markets that sell food to the consumers; where do citizens buy their food; what do people in the city region eat, where and how much food and organic waste is generated along the food chain, and how is it managed? The first phase of the assessment also looks into what are the strengths and vulnerabilities of the current CRFS for different dimensions of the food systems and for impacts in the different sustainability areas; to what extent the current food system (and different parts of the food system) are resilient to shocks and projected circumstances in the long-term; which areas of the city region, what parts of the food chain, and which groups of residents and involved stakeholders would be most adversely affected by vulnerabilities in the food system; what are the priority areas that need to be addressed in order to develop a more sustainable and resilient food system for the future, taking into account different sustainability dimensions and food system components; and what role and powers do the city's decision-makers and key stakeholders have in shaping a more sustainable/resilient food system that serves the city and the city region?

We carried out a literature review of existing relevant information at the local level, undertook secondary data collection, and also held multi-level stakeholder consultations to provide a rapid assessment of the food system. As a second step, guiding a more in-depth assessment on identified key issues, we developed an indicator framework to assess and monitor different dimensions and goals of a sustainable and resilient city region food system. Such goals or aims are related to the set characteristics of an "ideal" sustainable and resilient city region food system [35] and include, amongst others:

- To explore and strengthen the city region food production capacity and potential;

- To optimise the regional food processing capacity (that meets food safety standards and provides healthy and sustainable food to the population);

- To retain more of the "local food dollar" and position the city region agri-food sector to contribute directly to the regional economy; 
- To increase environmental sustainability and the resilience of the city region food system;

- To develop, implement, and monitor improved and more resilient city region food policies and strategies.

These indicators or outcome statements are also used to set out strategic directions to achieving specific aims and monitor changes resulting from (future) policy and programme implementation. Through a scenario building exercise, local governments may elaborate on the basis of multi-stakeholder participation and dialogue, strategies, and action plans to improve City Region Food Systems.

The multi-stakeholder dialogue process is a crucial step to building a framework for multi-level food governance. The success of such dialogue is measured in terms of policy intents or decisions taken that favour wider adoption of measures to improve sustainable and resilient City Region Food Systems. In this context, the approach recognises the great importance and added value of more qualitative consultation and participative processes balanced with more quantitative information and data collection and the use of assessment tools.

\subsection{Initial Findings from Case Studies in Medellín and Quito}

Although the implementation of the CRFS assessment project is still ongoing in all the pilot city regions, the programme has already contributed to existing local policy processes. This is illustrated by two case studies from Medellín and Quito.

\subsubsection{Case Study 1: Reinforcing Territorial Integration in the City Region Food System of Medellín}

Medellín is the second largest city in Colombia and the capital of the Department of Antioquia. It is located in the Aburrá Valley, a central region of the Andes Mountains in South America. The city has an estimated population of more than 2.4 million as of 2014. Medellín has faced years of violent civil war with dramatic implications. Rural refugees migrated to the city to escape ongoing violence in the outer regions. The city's informal communities continue to grow along the steep slopes and ridges away from the city centre [38]. This has contributed to bad living conditions associated with high levels of food insecurity and malnutrition in these areas.

Besides the rapid urbanisation process that encompassed the entire Aburrá Valley, the Antioquia Department presents a very diverse and complex territory in terms of social, geographical, agro-climatic, and environmental characteristics. This has often led to fragmented and uncoordinated territorial planning and inefficient food supply flows. As a result, the Aburrá Valley and the Antioquia region are highly dependent on external food provisioning (although 70\% of its territory is basically rural, the Aburrá Valley imports from outside $76 \%$ of its food consumption needs) and vulnerable to disruptions. Additionally, this implies an increase in transport costs, food losses and wastes, energy inefficiency, and, ultimately, higher prices for consumers.

However, significant efforts are underway to reduce the severity and prevalence of food insecurity throughout the city and the region. Indeed, the Medellín and Antioquia region in the last decade have taken a leading role within Colombia in pioneering with successful solutions to eradicate hunger and chronic malnutrition, and creating conditions of food self-sufficiency in the region. In this context, the city has recently launched an ambitious Plan for Food and Nutrition Security (SAN) for the period 2016-2028, aiming to ensure in the next 12 years a hunger-free and food-sovereign city.

As food availability and supply play a strategic and central role in the plan to meet city food needs, the understanding of the food system in the rural-urban continuum has become a priority, especially to identify strategies of territorial planning to: (i) facilitate the cooperation, coordination, and integration between producers and local markets; and (ii) to build a more equitable and functional relationship between rural and urban populations.

The political will to promote a process of territorial integration between city and rural areas has been constant in the last decades in Medellín. This found a political and institutional recognition 
with the creation of the Metropolitan Area of the Aburrá Valley in 1980 under Law 3104 of 1979, and subsequently with the formulation of the plan for Metropolitan Development, established in 1985 to address the increasing interdependence between Aburrá Valley and the rest of the department.

The FAO and RUAF programme is supporting the city of Medellin in defining the different areas of intervention and by bringing in a territorial perspective and a broader, more integrated, focus on spatial planning. In order to achieve a more territorial integration of public food policies, the city of Medellin, with the support of FAO and RUAF, is prompting an approach that conceives the city region as unit of intervention, promoting the development of more compact territorial environments and thus contributing to the reinforcement of the social tissue that will serve as the basis for food security. In this context the concept of the City Region Food System of Medellín served as starting point to identify strategies and policies to reinforce the food security in the territory.

As illustrated by Figure 1, the City Region Food System in the specific context of Medellín is defined as a multi-layer area following five different criteria: (i) food provisioning: the municipalities contributing more than $1 \%$ to the food provided to the supply centers; (ii) food production: municipalities contributing more than $1 \%$ of the total food production of the Department of Antioquia; (iii) proximity: those territories within the Aburrá Valley that currently have agricultural production; (iv) agricultural expansion: this criterion is related to the importance of the western Occidente subregion, which is conceived as an area of agricultural expansion within the overall development of the Antioquia department that is increasingly serving as a foodshed for the growing urban area of the Aburrá Valley, and includes the municipalities with the highest levels of agricultural activity; and, finally, (v) the political weight of some municipalities in Antioquia that, despite not contributing in a significant way to the production and supply of food products to Medellín, are considered important from an institutional point of view in terms of fostering territorial inclusion and governance.

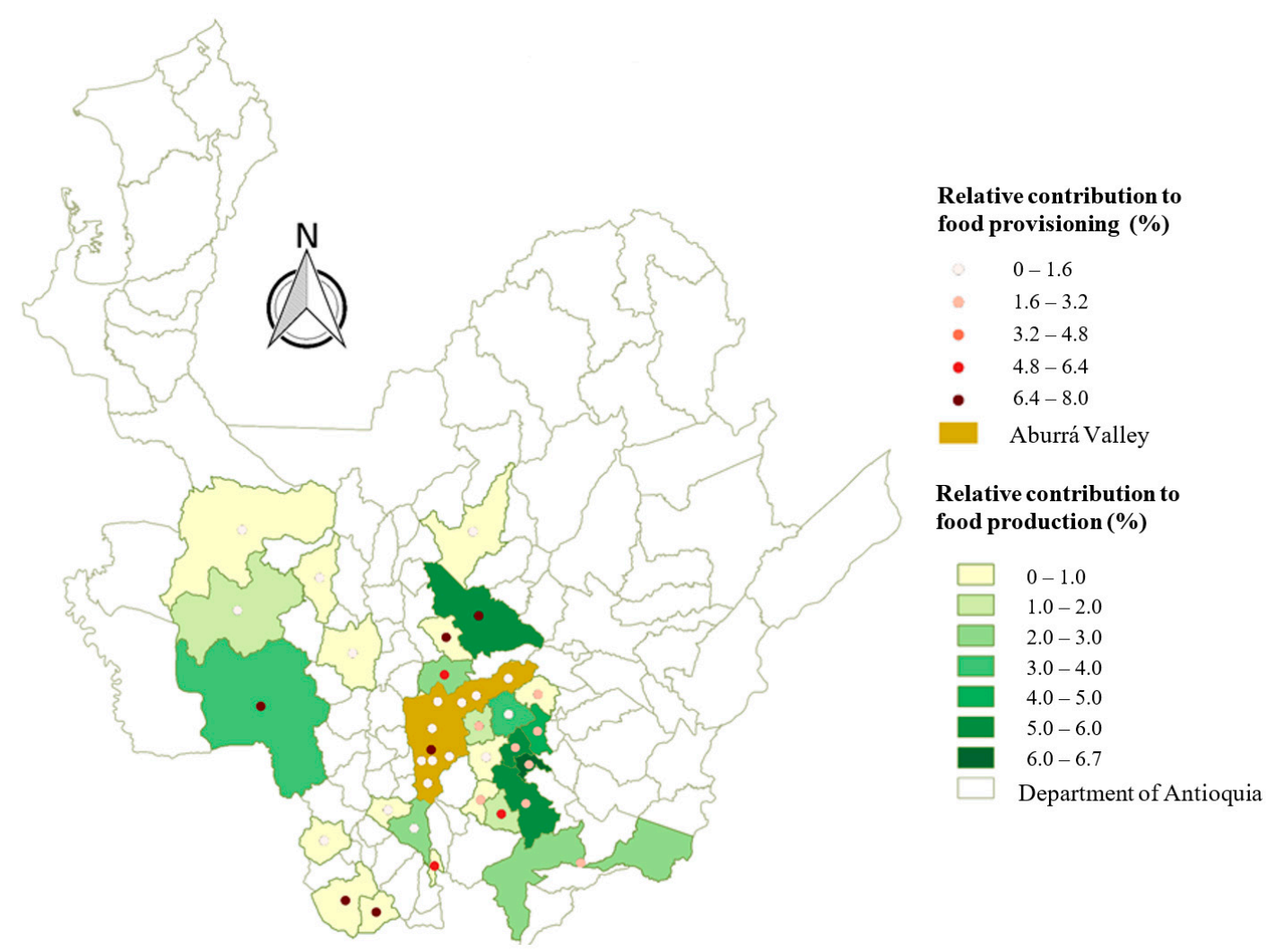

Figure 1. The city region food system of Medellín, Colombia (Source: FAO). 
Overall, the Department of Antioquia contributes nearly 30\% of the total food supply of the Aburrá Valley. The 31 municipalities that are part of the City Region Food System of Medellín and the food producing territory represent an area of approximately $2550 \mathrm{~km}^{2}$ and produce about 70 commodities totaling 670,440 tons in 2013. Figure 2 below indicates the contribution of the 31 individual municipalities making part of the Medellín CRFS to the overall food supply.

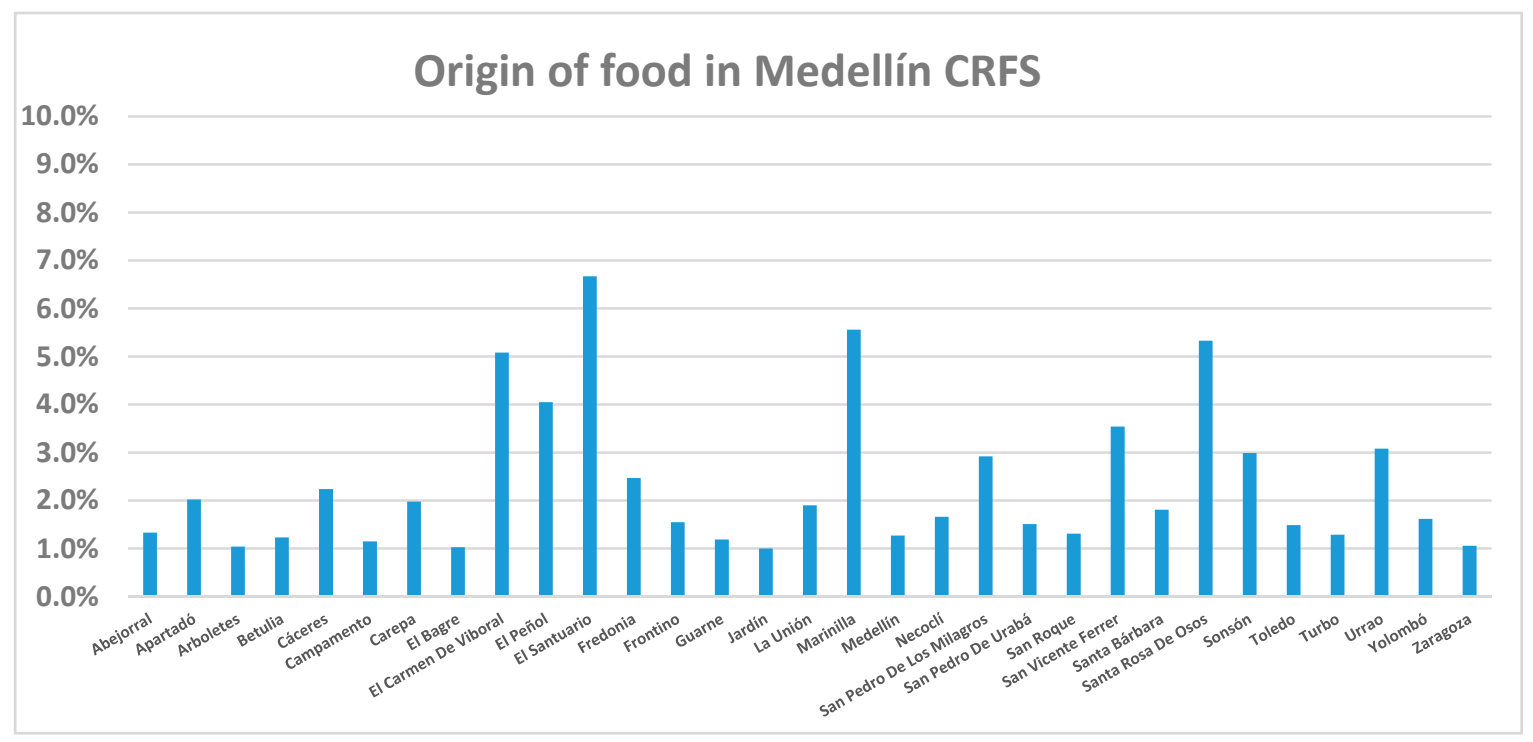

Figure 2. Contribution of municipalities in Antioquia to food in Medellín (Source: FAO).

Applying a CRFS approach has resulted in a more integrated and territorial perspective in defining the Food and Nutrition Security Plan for Medellín within the Antioquia region. This also requires governance mechanisms that address the complexity of regional food systems by strengthening rural urban linkages for more territorial integration and coordinated interventions between different government agencies and societal actors.

From this perspective, the CRFS approach contributes by: (i) creating an observatory and an indicator framework to monitor and evaluate food security and nutrition in the city region; (ii) creating institutional mechanisms for participatory governance and planning of the food supply for the city region starting from the institutional role of the Metropolitan Area of the Aburrá Valley and creating partnerships with neighbouring municipalities; (iii) identifying ways to make the city region's food supply and distribution system more inclusive and efficient by facilitating access of small food producers and low-income consumers to urban markets and re-connecting producers to consumers; (iv) redesigning urban spaces for activities contributing to improved food and nutrition security (urban gardens, popular canteens, food banks, food markets, etc.).

As a first result of these efforts, institutional integration between the Municipality of Medellín, the Metropolitan Area of Aburrá, and the Government of Antioquia was facilitated by the project, resulting in the creation of an inter-institutional taskforce for "Good Living" (Buen Vivir). This taskforce aims to generate political, administrative, and economic synergies, in order to facilitate the implementation of actions that strengthen the City Region Food System. More specifically, projects are following two directions: (i) supporting regional value chains and linking these to local food demand, thereby enhancing agricultural production and promoting sustainable and innovative production in the districts of Medellín; and (ii) improving the access and availability of safe and diverse food products for city region dwellers by strengthening the food supply and distribution system. 


\subsubsection{Case Study 2: From Urban Agriculture to Territorial Food Policies in Quito}

Quito, the capital city of Ecuador, is home to more than 2.2 million people, representing $15.5 \%$ of the total national population and $86.9 \%$ of the Pichincha province in which it is located [39]. Since 1990, Quito's urban growth has been characterised by low density extension and dispersion into the valleys surrounding the city, resulting in an urbanisation and industrialisation process of its peri-urban areas. In 2010, $72 \%$ of Quito's population lived in urban areas, whereas $28 \%$ lived in rural areas. This process of urban expansion has brought various challenges to the city such as urban poverty and food insecurity.

An important development in terms of governance structures and governability has been the establishment of the Metropolitan District of Quito (DMQ), which includes 32 urban parishes and 33 rural and sub-urban parishes. The new Ecuadorian Constitution of 2008 transferred to the Metropolitan District of Quito all competences of a regional government in an area comprising $44.6 \%$ of the surface of the province of Pichincha.

The Metropolitan District of Quito has an explicit policy objective to improve the livelihood conditions of its inhabitants in different aspects. According to its Strategic Development Plan 2015-2025, this requires addressing problems related to food insecurity, obesity, diet-related diseases, nutrition, and health. It also addresses the importance of environmental and waste management, and calls for the need to create income and employment opportunities through support to local productive value chains, sustainable agriculture, and local economic development in both rural and urban territories of the District [39].

Addressing such complex and interrelated challenges requires an integrated policy approach. The Metropolitan District of Quito government has been implementing a successful urban agriculture programme since 2002, under the umbrella of the AGRUPAR (Participatory Urban Agriculture) programme. After 14 years, AGRUPAR is now active in $87 \%$ of the urban and $82 \%$ of the rural parishes of the DMQ; it has established 2500 gardens with a total surface of 27 hectares, and produces 105 different food products. Almost half of the produce generated by the AGRUPAR farmers is commercialised, mainly through 14 biological farmers markets located in different areas of the District [40].

While the AGRUPAR programme has been successful in improving food sovereignty and better nutrition among the producer and consumer families involved in and reached by the programme, this intervention still remains far from sufficient in terms of its overall objective of reducing food insecurity and improving nutrition and food health in the Quito region. While the Quito municipal government recognises that the challenge of providing food security has become more and more an urban one, it also realizes that this requires strengthening interlinkages to surrounding rural areas as hubs for food production, food markets, and the location of natural resources. This requires a City Region Food System perspective to development that goes beyond the Metropolitan District Area. Therefore, in collaboration with the Agency of Commerce, agroecological markets for produce from rural producers outside the city are being established.

DMQ does not yet have a comprehensive urban or city region food policy, contrary to the case of Medellín. Its current challenge is to develop such a policy, building on its urban agriculture programme, other relevant projects, and private sector and civil society initiatives. A second challenge lies in linking DMQ strategies to initiatives and activities in the surrounding Pichincha Province in order to encompass a real city region and integrated territorial development perspective.

A promising new development in this respect has been the signing of the Milan Urban Food Policy Pact by the city of Quito in January 2016, which is committed to developing an integral city region food policy. As the concept of a city region is still new to Quito and Ecuador, RUAF supported Quito in defining its city region area to include the Metropolitan Districts' urban area (ca. $4000 \mathrm{~km}^{2}$ ) and its peri-urban and rural surrounding areas, as well as the surrounding provinces that play an important role in the supply, storage, and processing of food that is brought to Quito's markets.

In Figure 3, the City Region Food System (blue ring) thus includes major food production zones and markets to the North of Quito (provinces of Pichincha and Imbabura), to the South (located in the 
provinces of Cotopaxi, Tungurahua, Bolívar, Los Ríos, and Chimborazo), to the West (located in the provinces of Imbabura, Esmeraldas y Manabí), and to the East (provinces of Napo and Pastaza).

Working at the city region level allows us to better protect and support agricultural areas, to define areas for nature conservation and protection, and to plan for a more compact city and efficient food distribution system. This framework thus looks at ways to increase local food production, to support urban agriculture and rural family farming while increasing climate resilience, to develop short value chains, to increase direct producer-consumer linkages, and to promote more responsible and healthy consumption.

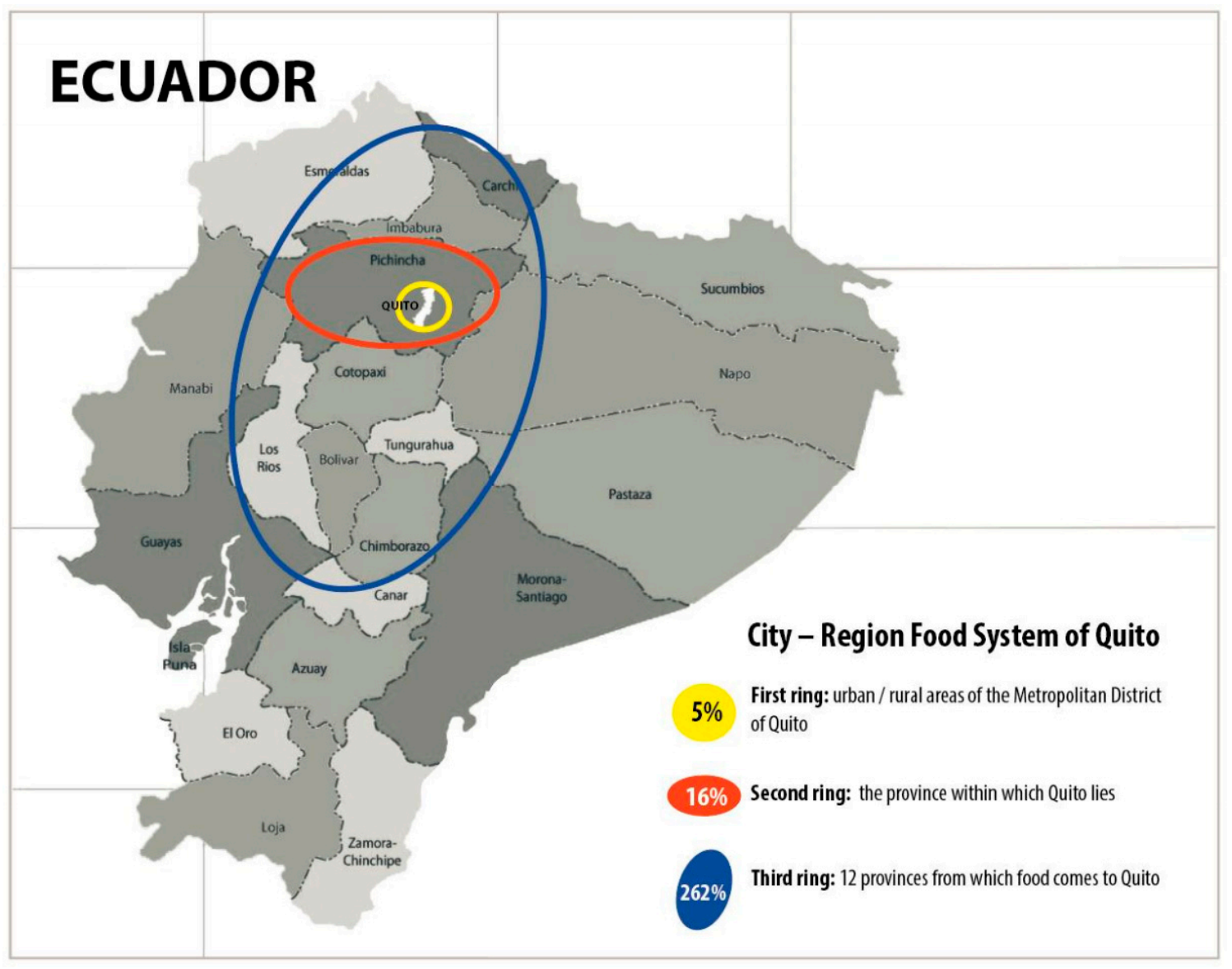

Figure 3. The city region food system of Quito, Ecuador (Source: RUAF).

Working at the level of the city region (extending beyond the Metropolitan District), however, requires coordination among local, provincial, and national governments. It requires bringing together Quito's urban and peri-urban agriculture programme and provincial and national rural agriculture programmes, working across jurisdictional boundaries. With political differences between the local, provincial, and national levels, such coordination is still a challenge.

\section{Discussion and Conclusions}

\subsection{Strategies for Improving the Sustainability and Resilience of CRFS}

While a lot of effort has been made by food movements to define what sustainable local food systems might look like, we find that still very little of the literature on territorial urban food systems defines sustainability and resilience very clearly. There is also very little clarity and agreement in current literature as to what degree higher self-sufficiency in a City Region Food System is both desirable and achievable. Important areas of attention to be explored further concern required 
institutional arrangements as well as the role and behaviour of actors from the private sector. The current work done by FAO and RUAF is one of the few and first attempts to better characterise the different components of a sustainable and resilient City Region Food System [35].

The food system assessment work in Medellín, Quito, and other city regions of the FAO and RUAF programme helped to identify several areas and sectors of change that may be required when establishing a clear future vision for the City Region Food System (see also [13,35]):

- Production: enhancing and optimising a more diverse city region food production capacity;

- Processing: providing a sufficient and appropriate regional food processing capacity (that meets food safety standards and provides healthy and sustainable food to the population);

- Distribution: increasing wholesale and distribution of regionally-produced food, making use of diverse outlets, e.g. markets, food supply hubs, and IT platforms;

- Retail: strengthening the presence of food outlets (shops, canteens, markets, street traders) that supply local and fresh healthy food to city residents; improved access to and use of the safe, healthy, nutritious, and culturally-appropriate city region food for vulnerable households/groups in sufficient quantities in the city region;

- Public catering and hospitality: public procurement to increase the offer of healthy, safe, and nutritious food;

- Waste: increasing engagement in the prevention and reduction of food waste and losses throughout the food chain, and increased recycling for safe human consumption;

- Local trade: promoting local consumption of local products to contribute directly to the regional economy;

- Local employment: creation of decent jobs and opportunities throughout the entire food chain, ensuring social inclusion, equity, and fairness for all workers;

- Circular economy: commitment and support to optimised recycling of nutrients, water, and energy for regional food production and wider environmental concerns.

\subsection{Mapping and Assessing CRFS}

The mapping and assessment of its food system helps a city region to better understand its dependence on and vulnerability to the food system. Many city regions lack data on how much and what type of food is consumed in their city (and by whom) and on where the city's supply of food comes from. Mapping food flows and their vulnerability to price and market distortions or to climatic influences helps to increase understanding of the city's dependence on imports from other provinces or countries. This may lead to greater awareness and attention for enhancing the resilience of their food system, especially in the context of further urban growth.

Assessing the food systems also helps cities to get more insight into different parts of the food system; the level of food security and the impacts of consumption (on nutrition or on the environment); the amount of jobs generated in the food distribution, processing, and retail industry; the amount of food production in the city region; and the amount of food waste and losses generated along the chain.

For example, CRFS assessment data from Lusaka (Zambia) highlighted the importance of the informal sector for low income households purchasing food items, calling for a specific support system for such informal markets. They also highlighted that Lusaka is receiving a relatively large quantity and proportion of its food (mainly vegetables, maize, and livestock) from surrounding rural areas, but also that quantities of local food arriving on the market are highly unstable. This requires, on the one hand, collaboration with bordering municipalities and the region to support development of rural agriculture; on the other, this needs to be harmonised with imports from other provinces/regions and from global commodity markets. Close-by rural production could continue to focus on perishable crops, especially as refrigerated supply chains are less common in Zambia. 
In a similar way, CRFS assessment made the city of Bristol (UK) aware of the importance of the food sector in local job creation, promoting the city to develop an action plan on how to enhance and increase localised food wholesale, processing, and retail in the Bristol city region [41].

\subsection{Need for Developing Integrated Territorial Governance Mechansisms}

The development of a sustainable and resilient City Region Food System requires political will and the creative use of available policy and planning instruments (infrastructure and logistics; public procurement; licences; land use planning, etc.); and the involvement of different government departments and jurisdictions (local and provincial) and new organisational structures at different scales (municipal, territorial, etc.).

As integrated city region food strategies cross different policy domains, one of the key challenges is to organise the administrative and political responsibility for an urban food strategy. To this end, City Region Food System assessment helps city authorities to recognise the links between food and various other sectoral policies, such as transport (a large part of city transport being food-related), health (malnutrition, obesity, school feeding), land use planning of agricultural and multi-functional areas, community development and revitalisation, employment generation (in food production, processing, and retail), waste management (productive use of waste and waste-water, management of food waste), and climate change adaptation and disaster risk-reduction (for example, localised food production reducing vulnerability to climate-induced food supply disruptions). This understanding helps city governments to start seeing food as a driver for other sustainable urbanisation policies.

For example, in Quito, with current risks of earthquakes and volcano eruptions negatively affecting the city region food supply, the city is reconsidering the functioning of the food storage and distribution systems in order to become less vulnerable to natural disasters. In Medellín and Colombo the CRFS assessment is contributing to better identifying ways to reduce food waste and losses from its sources, and to redistributing them to existing food banks and popular restaurants.

Working at the city region level helps cities to understand that their urban food security is dependent on rural production areas and how the food system impacts on both urban and rural populations. This promotes more integrated rural-urban planning as it did in Toronto, Canada. Toronto's city region is rich with agricultural lands (some of the best in Canada), a rapidly growing and diverse population, the second largest food hub in North America, and a robust cluster of research, agri-food processing, labour, and markets. Preservation of those areas and improvements in the food system such as shortened supply chains require looking beyond Toronto's boundaries to include so-called Great Golden Horseshoe area that involves Toronto Metropolitan Region and four surrounding municipalities.

Governance arrangements are the key reinforcement of a CRFS approach-putting the right structures in place to drive and facilitate the creation of new kinds of rural-urban linkages. A key challenge is creating more inclusive territorial governance structures in which cities, regions, and other levels of government can work constructively together towards complementary, beneficial outcomes $[2,6,9,12]$. In Quito, however, it is considered that due to weak technical, human, and resource capacities in rural governments (parishes or townships) this would require additional capacity building, empowerment, and financial resources. In addition, the involvement of subnational (provincial, county) governments is vital to addressing food systems, agriculture, food waste, and land use planning across several jurisdictions (outside municipal boundaries) and to ensuring the aggregation of rural and urban food production needed to offer consumers a diversified and sufficient, safe and nutritious supply of produce. They also play a crucial role in making available (additional) human and financial resources needed for programme implementation, for developing provincial level policies and programmes that accompany city-level strategies, and for supporting the scaling out of experiences to other areas [12].

On the other hand, new governance structures are not sufficient when these only take into account public bodies and government agencies. A key factor for the success of new territorial governance 
arrangements lies in the effective engagement of civil society actors in city region food policies. Active civic society engagement is, on the one hand, important to ensure that city region food policies are formulated in a sufficiently inclusive manner, and to ensure also that marginalized voices are represented. On the other hand, sufficient embeddedness and public support is an important factor to ensure the continuity of local food policies, especially in times of government transitions and when individual local leadership changes. More generally, a broad social basis for city region food policies and an adequate engagement of both civil society and private sector stakeholder groups appear to be key success factors for city region food policies. Governance arrangements such as Food Policy Councils and other multistakeholder platforms can play a key role in securing stakeholder engagement and as mechanism for participatory definition and coproduction of city region food policies.

The CRFS methodology applied by FAO and RUAF puts a lot of emphasis on spatially locating food system activities and impacts in relation to natural resource availability and social needs. This provides a basis for further spatial planning of the food system. In turn, such improved planning can help the food system to better respond to other urban and sustainability policies, as highlighted above. It is considered that the CRFS methodology supports the integration of food in strategic planning, as is being illustrated by the cases of Quito and Medellín. Similarly, the Toronto Golden Horseshoe Food and Farming Action Plan 2021 responds to the common challenges and opportunities that this rich agricultural area around Toronto shares. The Plan identifies pathways for a more integrated and coordinated approach to food and farming viability in the area to ensure that the Golden Horseshoe retains, enhances, and expands its role as a leading food and farming cluster. The Alliance coordinates and facilitates farm organisations' participation in food system planning and policy, as well as the input from various food industry associations and civil society organisations. All cities are working on specific tools with regards to food systems and spatial planning in order to 'regulate urban expansion on agricultural land, by preserving and protecting agricultural land from (un-planned) urban expansion and natural resources.' Enhancing producer access to secure tenancies is crucial in this regard. Other cities (like Belo Horizonte, Brasil) also show that local governments can support the development of innovative short food chains through the planning and development of designated areas for local traders that are visible, easily accessible, and supported with adequate facilities. Infrastructure is also needed for local food processing, storage, and food waste management, and needs to be located in proximity to sites of production and consumption, as well as in different parts of the city [13].

Acknowledgments: We acknowledge financial support for the research work of the FAO and RUAF City Region Food System assessment project by the German Federal Ministry of Food and Agriculture and the Daniel and Nina Carasso Foundation.

Author Contributions: Marielle Dubbeling, Guido Santini, Henk Renting, Makiko Taguchi and Louison Lançon contributed to the overall paper and specifically to Sections 1, 2,3.1 and 4. Authors Juan Zuluaga and Luca de Paoli mainly contributed to Section 3.2.1. Authors Alexandra Rodriguez and Verónica Andino mainly contributed to Section 3.2.2.

Conflicts of Interest: The authors declare no conflict of interest.

\section{References}

1. United Nations, Department of Economic and Social Affairs, Population Division. World Urbanization Prospects: The 2014 Revision, Highlights; United Nations: New York, NY, USA, 2014; 32p.

2. Jennings, S.; Cottee, J.; Curtis, T.; Miller, S. Food in an Urbanised World: The Role of City Region Food Systems in Resilience and Sustainable Development; 3Keel: London, UK, 2015.

3. Lang, T.; Heasman, M. Food Wars: The Global Battle for Mouths, Minds, and Markets; Earthscan: London, UK, 2004.

4. Berdegué, J.A.; Cazzuffi, C.; Proctor, F.J. Inclusive Rural-Urban Linkages. In Working Group Development with Territorial Cohesion; RIMISP: Santiago, Chili, 2014; 128p. 
5. International Food Policy Research Institute. Global Food Policy Report; International Food Policy Research Institute: Washington, DC, USA, 2017. Available online: http:/ /www.ifpri.org/publication/2017-globalfood-policy-report (accessed on 5 June 2017).

6. Forster, T.; Getz Escudero, A. City Regions as Landscapes for People, Food and Nature. EcoAgriculture Partners on Behalf of the Landscapes for People; Food and Nature Initiative: Washington, DC, USA, 2014.

7. International Panel of Experts on Sustainable Food Systems. What Makes Urban Food Policy Happen? Insights from Five Case Studies; International Panel of Experts on Sustainable Food Systems: Louvain-la-Neuve, Belgium, 2017.

8. De Schutter, O. Report of the Special Rapporteur on the Right to Food. Final Report: The Transformative Potential of the Right to Food; United Nations Human Rights Council: New York, NY, USA, 2014.

9. Forster, T.; Egal, F.; Getz Escudero, A.; Dubbeling, M.; Renting, H. Milan Urban Food Policy Pact: Selected Good Practices from Cities; Fondazione Giangiacomo Feltrinelli: Milan, Italy, 2015.

10. Global Forum for Food and Agriculture (GFFA). How to Feed Our Cities? - Agriculture and Rural Areas in an Era of Urbanisation. Communiqué 8th Berlin Agriculture Ministers' Summit, Berlin, Germany. 16 January 2016. Available online: https://www.bmel.de/SharedDocs/Downloads/Landwirtschaft/ Welternaehrung/GFFA_Kommuniqu\%C3\%A9_2016_EN.pdf (accessed on 5 June 2017).

11. United Nations. New Urban Agenda. Quito Declaration on Sustainable Cities and Human Settlements for All. In Proceedings of the United Nations Conference on Housing and Sustainable Urban Developmen, Quito, Ecuador, 17-20 October 2016.

12. Deutsche Gesellschaft für Internationale Zusammenarbeit (GIZ); RUAF Foundation; Food \& Agriculture Organization of the United Nations. City Region Food Systems and Food Waste Reduction-Linking Rural and Urban Areas for Sustainable and Resilient Development; Food \& Agriculture Organization of the United Nations: Roma, Italy, 2016.

13. Dubbeling, M.; Carey, J.; Hochberg, K. The Role of Private Sector in City Region Food Systems. Part I: Overall Analysis Report; RUAF: Leusden, The Netherlands; FBKN: The Hague, The Netherlands, 2016.

14. Wilkins, J.; Nadeau, R. A Companion to Food in the Ancient World; John Wiley \& Sons, Ltd.: West Sussex, UK, 2015; 457p.

15. RUAF Foundation. City Region Food Systems; Urban Agriculture Magazine: Leusden, The Netherlands, 2015; No. 29. Available online: http:/ / www.ruaf.org/ua-magazine-no-29-city-region-food-systems (accessed on 5 June 2017).

16. Van der Ploeg, J.D.; Long, A. (Eds.) Born from Within. Practice and Perspective of Endogenous Rural Development; Van Gorcum: Assen, The Netherlands, 1994; 298p.

17. Schejtman, A.; Berdegué, J. Towards a Territorial Approach for Rural Development; RIMISP, IPPG Discussion Papers 17; IPPG: Manchester, UK, 2008.

18. Lamine, C.; Renting, H.; Rossi, A.; Wiskerke, J.S.C.; Brunori, G. Agri-Food systems and territorial development: innovations: New dynamics and changing governance mechanisms. In Farming Systems Research into the 21st Century: The New Dynamic; Darnhofer, I., Ed.; Springer: Dordrecht, The Netherlands, 2012; pp. 229-256.

19. Peters, C.J.; Bills, N.L.; Wilkins, J.L.; Fick, G.W. Foodshed Analysis and Its Relevance to Sustainability. Renew. Agric. Food Syst. 2009, 24, 1-7. [CrossRef]

20. Hedden, W.P. How Great Cities are Fed; D.C. Heath and Company: New York, NY, USA, 1929.

21. Getz, A. Urban foodsheds. Permac. Act. 1991, 24, 26-27.

22. Kloppenburg, J., Jr.; Hendrickson, J.; Stevenson, G.W. Coming in to the foodshed. Agric. Hum. Values 1996, 13, 33-42. [CrossRef]

23. Metcalf, S.S.; Widener, M.J. Growing Buffalo's capacity for local food: A systems framework for sustainable agriculture. Appl. Geogr. 2011, 31, 1242-1251. [CrossRef]

24. Feagan, R. The place of food: Mapping out the 'local' in local food systems. Prog. Hum. Geogr. 2007, 31, 23-42. [CrossRef]

25. Morgan, K. Feeding the City: The Challenge of Urban Food Planning. Int. Plan. Stud. 2009, 14, 341-348. [CrossRef]

26. Moragues Faus, A.; Morgan, K. Reframing the foodscape: The emergent world of urban food policy. Environ. Plan. A 2015, 47, 1558-1573. [CrossRef] 
27. Renting, H.; Schermer, M.; Rossi, A. Building Food Democracy: Exploring Civic Food Networks and Newly Emerging Forms of Food Citizenship. Int. J. Sociol. Agric. Food 2012, 19, $289-307$.

28. Sonnino, R. The new geography of food security: Exploring the potential of urban food strategies. Geogr. J. 2014. [CrossRef]

29. Barling, D.; Lang, T.; Caraher, M. Joined-up food policy? The trials of governance, public policy and the food system. Soc. Policy Adm. 2002, 36, 556-574. [CrossRef]

30. Wiskerke, J.S.C. On Places Lost and Places Regained: Reflections on the Alternative Food Geography and Sustainable Regional Development. Int. Plan. Stud. 2009, 14, 369-387. [CrossRef]

31. Lang, T.; Barling, D.; Caraher, M. Food Policy. Integrating Heath, Environment E Society; Oxford University Press: Oxford, UK, 2009.

32. Morgan, K.J.; Sonnino, R. The urban foodscape: World cities and the new food equation. Camb. J. Reg. Econ. Soc. 2010, 3, 209-224. [CrossRef]

33. Baker, L.; de Zeeuw, H. Urban Food Policies and Programmes. In Cities and Agriculture, Developing Resilient Urban Food Systems; de Zeeuw, H., Drechsel, P., Eds.; Routledge: London, UK, 2015; 431p.

34. Pimbert, M. Towards Food Sovereignty; The gatekeeper series (141); IIED: London, UK, 2009; 24p.

35. Food and Agriculture Organization of the United Nations (FAO); RUAF Foundation. A Vision for City Region Food Systems. 2015. Available online: http:/ / www.fao.org/3/a-i4789e.pdf (accessed on 5 June 2017).

36. Desakota Study Team. Re-Imagining the Rural-Urban Continuum: Understanding the Role Ecosystem Services Play in the Livelihoods of the Poor in Desakota Regions Undergoing Rapid Change; Institute for Social and Environmental Transition-Nepal (ISET-N): Kathmandu, Nepal, 2008; 125p, ISBN 978-9937-8019-1-1.

37. High Level Panel of Experts (HLPE). Food Losses and Waste in the Context of Sustainable Food Systems; A Report by the High Level Panel of Experts on Food Security and Nutrition of the Committee on World Food Security; HLPE: Rome, Italy, 2014.

38. Laidlaw, J. Food Security - A Core Component of a Leading City's Transformation Agenda; Global Compact Cities Programme; RMIT University: Melbourne, Australia, 2015.

39. Distrito Metropolitano De Quito. Plan Estratégico Metropolitano de Desarrollo y de Ordenamiento Territorial del Distrito Metropolitano de Quito; Alcaldia de Quito: Quito, Ecuador, 2015. (In Spanish)

40. Rodriguez, A.; Proaño, I. Quito Siembra: Agricultura Urbana; CONQUITO AGRUPAR: Quito, Ecuador; Alcaldia de Quito: Quito, Ecuador, 2016. Available online: http://www.conquito.org.ec/wp-content/ uploads/2016/11/QUITO_SIEMBRA_AGRICULTURA_URBANA_CONQUITO.pdf. (accessed on 15 August 2017). (In Spanish)

41. Carey, J. Who Feeds Bristol? Towards a Resilient Food Plan; Bristol Green Capital and Bristol City Council: Bristol, UK, 2011.

(C) 2017 by the authors. Licensee MDPI, Basel, Switzerland. This article is an open access article distributed under the terms and conditions of the Creative Commons Attribution (CC BY) license (http://creativecommons.org/licenses/by/4.0/). 